\title{
The Shortest Way to Modernity Is via the Margins: J.H. Prynne's Later Poetry
}

\section{ABSTRACT}

In the essay an attempt is made to investigate the processes of construction and reconstruction of meaning in the later books of the Cambridge poet J.H. Prynne. It has been argued that his poetry disturbs the act of meaning-making in a ceaseless experimental reconnection of words taken from multifarious discourses, ranging from economics to theology. Yet, what appears striking in this poetry is the fact that these lyrics take their force from figurative meaning with which the words are endowed in the process of a poem's unfolding. Prynne appears to compose his lyrics by juxtaposing words that in themselves (or sometimes in small clusters) do yield a meaning but together exude an aura of unintelligibility. We may see this process as aiming at the destruction of what might be posited as the centre of signification of the modern language by constantly dispersing the meaning to the fringes of understanding. The poems force the reader to look to the margins of their meaning in the sense that the signification of the entire lyric is an unstable composite of figurative meanings of this lyric's individual words and phrases. To approach this poetry a need arises to read along the lines of what is here termed "fleeting assertion"; it is not that Prynne's poems debar centre in favour of, for instance, Derridean freeplay but rather that they seek to ever attempt to erect a centre through the influx from the margins of signification. Therefore they call for strong interpretive assertions without which they veer close to an absurdity of incomprehension; however, those assertions must always be geared to accepting disparate significatory influxes. Indeed, interpretation becomes a desperate chase after "seeing anew" with language but, at the same time, a chase that must a priori come to terms with the fact that this new vision will forever remain in the making. 
The path literary modernism seems to have traversed since the beginning of the twentieth century until the present moment may be described as a journey from the centre (aesthetic, cultural, metaphysical) to the margins. However it is defined, the modernist mode has by now become a spectral presence, hovering over the outermost ridges of writing practice. To some extent this fate lay in the very notion as promoted by the High Modernist writers of the Anglo-Irish tradition, with their emphasis on the artist's separation from the tarnished popular culture. Of course, here a distinction between two modernities must be stressed; on the one hand, modernism is "a product of scientific and technological progress, of the industrial revolution, of the sweeping economic and social changes brought about by capitalism"; on the other, it is "an aesthetic concept" that percolated down to the histories of literature (Calinescu 41). The latter may then be characterized by its immersion in "the structural and philosophical presuppositions of myth and depth psychology" (Holquist 135). Elitism of the Eliot/Pound strain of modernist letters is countered by the American climate, which as early as in 1922 was voiced by Matthew Josephson, who observed that "the true innovation of American modernism lay precisely in its fusion of experimentalism and popular culture" (Kalaidjian 4). This inner plurality of stances towards modernism notwithstanding, the characteristic features of modernist $\operatorname{art}^{1}$ no longer define the core of contemporary writing.

Yet modernist poetics, especially the early experimental and playful kind, survives until the present, even to the extent that, and here Marjorie Perloff must be credited with the clearest enunciation of that fact, American poets such as Susan Howe, Charles Bernstein, Lyn Hejinian and Steve McCaffery are at times referred to as "the second wave of modernism" (Perloff, 21st-Century Modernism 5). Perloff mentions in passing that the second wave of modernist poets is not limited to the US but embraces all nations that participated in the creation of what Hugh Kenner, after Bradbury and McFaralane, convincingly termed "international modernism"; still, the fact remains that the popularity of modernism in its avantgarde form has fused with a plethora of other aesthetic formations. What retains the scent of novelty and potentiality for the current writing is the irrepressible experimentalism that comes from the indomitable men of letters of the early twentieth century. In the present essay the focus is placed on the many-aspect notion of marginality in the work of J.H. Prynne, who

1 Those are lucidly laid out by Michael Whitworth in his introduction to modernism $(10-16)$. 
has willingly chosen an ephemeral and furtive presence among the contemporary poets.

Critics, who chant his inexplicability as insistently as their counterparts did the weirdness of, for example, Pound's Cantos, tend to concur with the view that Prynne is a late-modernist poet (Corcoran 174; Hampson and Montgomery 82; Mellors 19; Reeve and Kerridge 1). Hampson and Montgomery pertinently note that Prynne's poetics "has its basis in classical modernist techniques such as multiplicity of discourses and the absence of a consistent speaking subject" and add that his recent work "frequently uses multiple vocabularies to monitor the ethical impasses that confront the individual enmeshed in the signifying systems of late capitalism" (83). Corcoran ends his short evaluation of Prynne's work of the 1968-1980s period by expressing some reservations about the progressing ambiguity with which this poetry is rife. However, since the modernist principles which Prynne employs deliberately draw from the experimental art of Pound and Charles Olson (Corcoran 82), it is no wonder he veers towards the outermost fringes of linguistic productivity, juggling various idioms and deploying multifarious references to past literatures (not only English and American but also, notably, Chinese).

Prynne's later work shares with early modernism a pleasure in constantly pressing language beyond the limits of meaning so that it begins to yield a quality that shuns typical elucidatory procedures centred on the coherent signifying utterances. This drive towards opening language to unexplored regions of its potential forces the poems to seek a path leading beyond the acknowledged scope of meaning to the margins of iterability. The volumes after Kitchen Poems orient themselves decidedly onto the frontiers of expression in a deliberate leap in the direction of perpetual (for Eliot, fervent supporter of the centre in his later work, a favourite word) breaking apart and reconstruction. Critically, the poems easily eschew whatever theoretical assumption the interpreter should bring into play inasmuch as each of their metaphorically-metonymic phrasings is an "occasion for learning [a] new meaning” (Davidson, Inquiries 251). Therefore, to approach Prynne's later work is to decidedly think oneself into a position of what I would term "fleeting assertion." This idea can be traced back to Donald Davidson's conception of passing theory, which "is derived by wit, luck, and wisdom from a private vocabulary and grammar, knowledge of the ways people get their point across, and rules of thumb for figuring out what deviations from the dictionary are most likely" (Davidson, Truth 107). Thus passing theory is predicated on the contingent use of interpretive methods and "is geared to the occasion" of a particular interpretation of the meaning of an utterance or, for that matter, text. There is no prior theory that could explicate any utterance unless it is applied recursively (Truth 101). 
It is this claim that makes Davidson a worthy literary theoretician rather than his slightly dubious postulate of intended meaning, which has been taken as his major insight in the sphere of literary theory (Wheeler 189-90). Passing theory may, as it seems, be argued to be a crucial input in the practice of criticism in that it stresses the fact that every utterance has a decipherable meaning which must overlap with the interpreter's in order for this meaning to be apprehended. Granted that we perceive the world, as Davidson asseverates, not through language but through having a language (Truth 141), that is, by means of having a faculty of language similar to the faculty of sight or taste and not through eyes or taste-buds, it becomes clear that the interpreter must either share the general perception of the world or learn to literally "see" with the speaker's language. Under such circumstances no preconception can last and no postulate can shirk change; as a result the reading process turns into a series of interpretative twists and leaps: what has been called fleeting assertions. Such a notion of interpretation does not relinquish the idea of centre but, importantly, envisions it as a contingent derivative of a conversational situation where a text is taken as the partner in conversation with the interpreter, following a cue given by Bartczak (10); thus the centre becomes a result of the play on the margins. It is not the case that we cannot understand a text but rather that we decline to embrace its point of view.

This theoretical introduction is needed to pave the way back to Prynne, since his poetry is nothing if not an invitation to "see" with the poems' idiom, barring final assertions. To step out of the simple declarative construction of language which has proven notoriously difficult to escape, the poems give up traditional punctuation and employ a congeries of phrases ostensibly arranged at random. In his last book of poems in the twentieth century, Pearls That Were, Prynne juxtaposes various jargons so as to extract their rhetorical potential. In "Ever much missed," the nondescript speaker, who more likely than not appears to be a mixture of various voices eavesdropped on, explains the constructional feature of this poetics:

\footnotetext{
... freedom to make more graces to shade

its wildish, loose arraignment under loan to decide.
}

Who it is precisely that is free to make more graces and whose wildish arraignment the poem mentions remain unclear and perhaps not to be explicated. Further, there are two verbs referring to arraignment, which is either to be shaded or, transitively, is to decide; also the loan cannot 
readily be accounted for. Despite this bewilderment, the stanza courts a feasible reading by attracting attention to the peculiar use of the legal word; "arraign" through Old French comes from Latin "reason, account" ("Arraign"). The poem thus reveals its rhetorical texture which seeks to make its subject matter the very fact of the poem's existence. "Loose arraignment" explains the poem itself. Phrases are joined together to create a contingent account of the act of creation of language which is to be shaded-why it is to be so we thus far do not know. Still, the phrase appears to lay bare the structural machine underpinning the lyrics in the volume inasmuch as they are loosely arraigned, randomly called upon to appear before the high court of reason.

What this loose arraignment leads to are "Derisive permutated fictions" of the last stanza. Of all lines in Prynne's oeuvre there are few that match this one in the power of evocation. The line opens the path to the rhetoric plenitude of Prynne's poetry in that each following poem, each succeeding line, is an attempt at a fiction, a supreme fiction, one could add, in line with the absurdly powerful "Chieftain Iffucan of Azcan" of "Bantams in Pine-Woods." Like language in Davidson's view forever capable of new uses thanks to the existence of metaphor that joins known words into unheard-of phrases, these lyrics try to name what has not yet been named. ${ }^{2}$ Hence their derisive quality; there is no final explication of those permutated fictions, since "each one / discount [s] as neatly"; instead they require an approach that would fully appreciate their changeability.

However, it is not a Derridean freeplay that the poem boasts, but rather a Davidsonian constant recreation and redeployment of passing centres of communicative situations as the poems display a "floating / levity of design." Whilst "floating" might indicate that the poems assume freeplay as their defining feature, "levity of design" stresses the fact that they keep striving after a form, if not of mythical order, then surely of a frivolous linguistic insight. The seriousness vested in this design of "permutated fictions" stems from the biblical connotation of "levity" to The Leviticus, the book of laws, but at the same time it is mitigated by a humorous lack of respect that lies at the core of the modern meaning of the word. The "design" must be as equivocal as the "levity" itself that conjoins two overtly irreconcilable meanings of frivolity and grave respectfulness. Whilst the poems sustain a rise (indeed, a levitation) in unbearable lightness of signification and phrase-spinning, they remain intransigent about the need

2 Davidson, in congruence with Richard Rorty, argues that "learning to interpret a word that expresses a concept we do not have is a far deeper and more interesting phenomenon than explaining the ability to use a word new to us for an old concept" (Truth 100). 
for a particular structure, albeit one "redressed in motion" ("Sent out to tender" from Pearls That Were).

This tension between seriousness and levity may be generalized into a grander (if still passing) theory of Prynne's poetry. If by gravity we understand the need for assertion and by frivolity the distance kept from even the slightest possibility of making a declarative point, then "levity of design" is what we are left with. On the one hand, a search for an increased expressive power; on the other, an accepted knowledge that only through experiment can this power be achieved, thus it must remain forever on the margins that language may be permutated into a newer expression. This position is restated in the final two stanzas of "Damp to level."

Up in sparkling glee, over wide salt sea oh madam don't be coy

for all your glory, fear of another day and another story.

Across the thread a hooked undertow that could rant and roar over the level slit of its horizon, lifted in fierce, disordered pleasure.

The opening sets in a mirthful mood that exudes an air of flirtatious disportment on the part of the speaker. A reference to "To His Coy Mistress" introduces a lightness of mood that conjures up the defiant call of love from the last couplet of Marvell's poem. The speaker in Prynne's lyric asks the lady to conquer her fear of "another story," which together with the speaker they could begin to tell. Rhetorically, however, Prynne substitutes the sexual drive that motivates Marvell's speaker for a narrative motivation in his poem. Whereas in "To His Coy Mistress" the language is subservient to the desire to coax the lady into starting an affair, in "Damp to level" it appears that it is the act of spinning the tale of love that is paramount in the speaker's mind.

This hankering after "another story" is carried over to the last stanza where the "wide salt sea" is again alluded to. Yet, the mention of the "hooked undertow," a passing reference to the nautical jargon similar to the use of legal "arraign," seems to recall the double-bound "levity of design" in that the undertow always moves in a different direction to that of the surface current. Thus the speaker hints at the "undertow" of the poems, which is the rhetorical layer of the images that relate back to themselves in an act of fictional permutation down the paradigmatic axis of figuration. The undertow can now "rant and roar" (an enlivening of the tiresome "rant and rave") over the flatness of its horizon; the cha- 
grin of the underlying rhetorical level of the poem is directed against the necessary linking of language with nature insomuch as, in a sudden flair of imagination, a part of natural assortment of the world takes issue with its own obviousness. The poem looks beyond the simple sentences that to Davidson determine our generally true perception of the world (Sosa 174), all the way to the newness of figurative re-apprehension of reality.

Language in the modernist mode struggles to regain an initial contact with nature, it seeks to be the world it describes as in the definition of objective correlative; it also tries to construct images that would be the thing they evoke, not merely symbolize an unwarranted vision. All these features are then to be filtered through dynamic, vorticist syntax in order to express the complexity of the world. Those are mottos of modernism spawned mainly by Pound and Eliot, but they still apply to Prynne. What distinguishes him from the High Modernists, if not from Joyce in the more saucy fragments of Ulysses and all of Finnegans Wake (especially in Davidson's analysis), is the "disordered pleasure." To Prynne, the medium of language, even when put in poetry, is stripped of the noumenal. To write poetry is tantamount to feeling joy derived from incessant disorganization done underneath the literal layer. "Disorganized pleasure" stems from "derisive, permutated fictions" and "levity of design." This postulate follows on from Davidson's famous proposition that "a metaphor does not say anything beyond its literal meaning" in the sense that the figuration which is triggered by the disordered pleasure is aimed to make us notice the endless connections between things (both within the world and along the axis of figurative or rhetorical meanings) (Truth 257, 262). This can be done only on the margins of meaning and as a result of indomitable experimentation which keeps trying to "explode the text up on stage" (Triodes, Book II), since what is at stake is the freedom of loose arraignment of the levity of design.

Dead metaphors are seen as agents of rhetoric oppression, as in an ending fragment of "The scores read like this" from Triodes, Book III:

The crime of the rational script permits a script of crime in time to calibrate the forces of pent-up sentence: word by word.

If "the rational script" has its way, all the crimes it entails, such as exclusion of minority, ban of any differences from the preponderate "normal" and the right to civil disobedience, will have enough time to gather strength. Importantly, Prynne is quick to notice that the oppressive forces of "the rational script" first locate themselves in linguistic practice into which they sift slowly but unstoppably. What this results in is the "pent- 
up sentence" or language suppressed. The centre, artificially sustained in everyday use of language, forces an arbitrary praxis under the guise of the natural state of being (quite similar to Barthes's mythology as a secondorder semiotic system).

This fragment of Triodes, Book III openly tackles the horrible notion of eugenics that became a part of the modernist agenda in the 1920s and 30s. It many ways the concept stemmed directly from what Prynne calls "the rational script" and gained support because it "was in many ways radical and forward-looking. It was based on the new, dynamic science of evolution and was defined by equally new mathematical techniques that became the foundations of modern statistics" (Soloway 27). All the most renowned modernist writers, at least for a moment, subscribed to the idea. D. H. Lawrence supported it in the letter where he writes of a lethal chamber (81) so vividly evocative of the Nazi concentration camps; both Eliot and Yeats associated eugenics with development of society, each picturing it in a slightly different way (Bradshaw 44, 48). All those heinous aspects of modernism scud in the background of Prynne's poem. He ascribes them to rational linguistic practice (Davidsonian seeing through having a language). It is just that such a language is necessarily deranged and stifled out of its natural malleability; where those repressed, "pent-up sentences" can find relief are the margins. Modernism was after all the period which saw the emergence of psychoanalysis as practised by Freud and Melanie Klein, who investigated the psyche's "revolutionary mass, occluded rhythms, surreptitious discourses, repressed desires," in other words traced what was beneath the surface of consciousness and understood it to be infinitely chaotic, confused and phantasmagoric (Frosh 135); through letting go of the constraints put on language the depths of our selves could be unveiled.

This tension between order and constant dissipation comes back in full swing in Blue Slides at Rest (2004). The poems are formally regular in the way that Perloff understood William Carlos Williams's later poems to be regular ("To Give a Design" 89-91), but words constantly thwart our attempts at sustaining an interpretation. Whilst the lyrics look ordered when seen on page, they explode ("up on stage," to refer to the ending poem of Triodes, Book II) each meaning with every following word:

Partition blurred caloric engine his spiral transfusion playful to flex, inherent tuneful quantity. Both recessive to malabsorb, lapse of thought. Neither remembered this.

What is striking is that there are two forces clashing with each other. On the one hand, there is the centripetal drive that strives to erect a fullfledged image (added to it must be the fact that all poems are divided 
into two twelve-line stanzas and there are ten poems altogether, clearly a structural agenda underlies the volume); on the other, with each new beginning the phrases centrifugally fail to come to a plausible finish. "Partition," suggesting division so as to form a new array, is deflected by the subsequent "blurring." The "caloric engine," first put to use in the early nineteenth century, produces mechanical work as a result of the process of heating up and subsequent cooling of air, hence "flexing" in the second line of the poem, which evokes the work of human muscles; yet the energy produced by the engine is playful, for it is used in order to extract the "inherent tuneful quantity" from composing the words on the page. At the same time, the comma after "flex" separates the verb from its object, which would otherwise turn the largely disjointed phrases into a coherent sentence. A similar punctuation ploy occurs in "recessive / to malabsorb, lapse of thought," since without the comma malabsorbing would link with "lapse of thought," making the sentence, if not regularly understandable, then figuratively acceptable. However, the task in the poem is to confront two opposing forces, and this is done unwaveringly. The number two figures in these lines only furtively in that "both" and "neither" hint at the fact that the lyric is dealing with two drives which sometimes concur with each other and sometimes conflict. What matters here is that one should never be "in all for all in." This phrase calls for what has been called fleeting assertion inasmuch as the condition for "seeing" the world of the poem is changeability; never, the poem (for the word "speaker" seems far too incongruent) suggests, should one be "all for" being "all in." There is no totality, no gross price one has to pay to enter the text, for there is no single entrance but a "flowing bastion gate."

Thus "Bind will," if you must bind something, as the path through this "cambium shower" demands that you surrender the desire to "fall back" and "press on," instead you should persist in spinning ephemeral interpretations of those elusive texts whose "principle [is] stamen"; the word "stamen" denotes "a male fertilizing organ of a flower" ("Stamen") and thus seems to be a figurative reference to dissemination. The lyric, it appears, piles layer after layer of rhetorical devices one on top of another in a wild metaleptic leap. Despite this seeming principle of unrestrained freeplay, there is a strong emphasis on what may best be described as "the shadow unendurably now calibrated" "Cranial flat-bed declension" from Biting the Air). The poems are thus spread between "the shadow" zone of the limitless play (perhaps the fringes of meaning) and the calibration which seeks to correlate the text of the poem with the reader who comes to the text to "see with" it. Thus the task and the oft-mentioned difficulty of Prynne's poetry may be that, in a hardcore avant-garde manner reminiscent of the Joyce of Finnegans Wake, it—as Davidson put it in his 
essay on Joyce-forces us to "share in the annihilation of old meaning and the creation-not really ex nibilo, but on the basis of our stock of common lore-of a new language" (Truth 157). The variety of jargons Prynne claims in his poems, from astronomy to zoology, is aimed at the stirring of "Dull roots with spring rain"; in a manner akin to the modernists of the early twentieth century, these lyrics "Have words / not joined to fit right" ("Each one tissue-wrapped phoneme sedative" from Blue Slides at Rest). In lieu of rightness, Prynne offers energy, the power that words which customarily do not fit together produce when rolling against each other. It is this force, always coming to the fore from the outermost limits of linguistic expression, that mandates the production of meaning and finds the means of description of what so far has never even come to exist at all.

\section{Works CITED}

“Arraign." Oxford Concise English Dictionary. 10th ed. 1999. Print.

Bartczak, Kacper. Świat nie scalony. Wrocław: Biuro Literackie, 2009. Print.

Bradshaw, David. "Eugenics: 'They Should Certainly be Killed." A Concise Companion to Modernism. Ed. David Bradshaw. London: Blackwell, 2005. 34-55. Print.

Calinescu, Matei. Faces of Modernity: Avant-Garde, Decadence, Kitsch. Bloomington: Indiana UP, 1977. Print.

Corcoran, Neil. English Poetry Since 1940. London: Longman, 1993. Print.

Davidson, Donald. Inquiries into Truth and Interpretation. Oxford: Clarendon, 2001. Print.

---. Truth, Language, and History. Oxford: Oxford UP, 2005. Print.

Frosh, Stephen. "Psychoanalysis in Britain: 'Rituals of Destruction." A Concise Companion to Modernism. Ed. David Bradshaw. London: Blackwell, 2005. 116-37. Print.

Hampson, Robert, and Will Montgomery. "Innovations in Poetry." The Oxford Handbook of Modernisms. Ed. Peter Brooker et al. London: Oxford UP, 2011. 63-279. Print.

Holquist, Michael. "Whodunit and Other Questions: Metaphysical Detective Stories in Post-War Fiction.” New Literary History 3 (1971): 135-56. Print.

Kalaidjian, Walter. Introduction. The Cambridge Companion to American Modernism. Ed. Walter Kalaidjian. New York: Cambridge UP, 2008. 1-11. Print. 
Lawrence, D.H. The Letters of D.H. Lawrence. Ed. James T. Boulton. Vol. 1. Cambridge: Cambridge UP, 1979. Print.

Mellors, Anthony. Late Modernist Poetics. Manchester: Manchester UP, 2005. Print.

Perloff, Marjorie. 21st-Century Modernism. Malden: Blackwell, 2002. Print.

---. "To Give a Design': Williams and the Visualisation of Poetry." Dance of the Intellect: Studies in the Poetry of the Pound Tradition. Evanston: Northwestern UP, 1996. 88-118. Print.

Prynne, J.H. Poems. Tarset: Bloodaxe, 2005. Print.

Reeve, N.H., and Richard Kerridge. Nearly Too Much: The Poetry of J.H. Prynne. Liverpool: Liverpool UP, 1996. Print.

Soloway, Richard. Demography and Degeneration: Eugenics and the Declining Birthrate in Twentieth Century Britain. Chapel Hill: U of North Carolina P, 1990. Print.

Sosa, Ernest. "Knowledge of Self, Others, and World." Donald Davidson. Ed. Kirk Ludwig. New York: Cambridge UP, 2003. 163-82. Print.

"Stamen." Oxford Concise English Dictionary. 10th ed. 1999. Print.

Wheeler, C. Samuel III. "Language and Literature." Donald Davidson. Ed. Kirk Ludwig. New York: Cambridge UP, 2003. 183-206. Print.

Whitworth, Michael H. Modernism. New York: Blackwell, 2007. Print. 